\title{
Plant regulators on the growth, quality and production of 'Tommy Atkins' mango fruits
}

\author{
João Bosco Nunes Bezerra ${ }^{1}$, Paulo Ricardo Rodrigues de Jesus ${ }^{1}$, Igor Dias Souza ${ }^{2}$, \\ Willian Costa Bezerra², Glória Caroline Santos Barboza Martins², Valtemir Gonçalves Ribeiro ${ }^{3}$ \\ Abstract - The objective of this study was to evaluate the effect of cytokinin (BAP) and gibberellin \\ $\left(\mathrm{GA}_{3}\right)$ applications on the growth, physicochemical characteristics and production of "Tommy \\ Atkins' mango fruits. Mango plants were sprayed with five concentrations $(0,75,150,225$ and \\ $\left.300 \mathrm{mg} \cdot \mathrm{L}^{-1}\right)$ of BAP and $\mathrm{GA}_{3}$ and BAP $+\mathrm{GA}_{3}(0,75+75,150+150,225+225$ and $300+300$

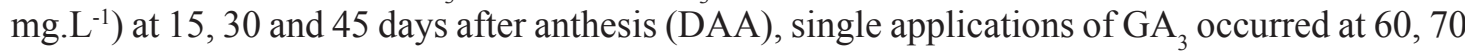 \\ and 80 DAA. Fruits were evaluated weekly from 52 DAA for weight, diameter and length until \\ harvest and characterized for soluble solids content and acidity. A higher peak of fruit growth \\ occurred between 66 and 73 DAA. Application of $150+150 \mathrm{mg} \cdot \mathrm{L}^{-1}\left(\mathrm{BAP}+\mathrm{GA}_{3}\right)$ promoted at \\ the end of the evaluation period higher fruit weight compared to the other treatments and the \\ control. No significant differences were observed in fruit production, but also concentrations of \\ $150+150 \mathrm{mg} \cdot \mathrm{L}^{-1} \mathrm{BAP}+\mathrm{GA}_{3}$ led to more than $50 \%$ of fruits in the marketing standard type 8. \\ Exogenous application of $150+150 \mathrm{mg} \cdot \mathrm{L}^{-1}\left(\mathrm{BAP}+\mathrm{GA}_{3}\right)$ at 15, 30 and 45 DAA increased the \\ weight, diameter, length, acidity and the percentage of fruits type 8 of 'Tommy Atkins' mango, \\ but it did not increase yield. \\ Index terms: Semiarid region; 6-benzylaminopurine; Gibberellic acid; Mangifera indica L.

\section{Fitorreguladores no crescimento, qualidade e produção de frutos de mangueira 'Tommy Atkins'}

Corresponding author: jbconsulagri@hotmail.com

Received: December 08, 2020 Accepted: March 22, 2021

Copyright: All the contents of this journal, except where otherwise noted, is licensed under a Creative Commons Attribution License.

\section{$($ (cc) $\mathbf{E Y}$}

Resumo - O objetivo deste trabalho foi avaliar o efeito de aplicações de citocininas (BAP) e giberelinas $\left(\mathrm{GA}_{3}\right)$ no crescimento, nas características físico-químicas e na produção de frutos de mangueira 'Tommy Atkins'. Plantas de mangueiras foram pulverizadas com cinco concentrações $\left(0 ; 75 ; 150 ; 225\right.$ e 300 mg. $\left.\mathrm{L}^{-1}\right)$ de BAP e GA e de BAP $+\mathrm{GA}_{3}(0 ; 75+75 ; 150+150 ; 225+225$ e $300+300 \mathrm{mg}^{-\mathrm{L}^{-1}}$ ), aos $15 ; 30$ e 45 dias após a antese (DAA), e as aplicações isoladas de $\mathrm{GA}_{3}$ ocorreram aos 60; 70 e 80 DAA. Os frutos foram avaliados semanalmente, a partir de 52 DAA, medindo-se a massa, o diâmetro e o comprimento até à colheita, e caracterizados o teor de sólidos solúveis e a acidez. Entre 66 e 73 DAA, ocorreu maior pico de crescimento dos frutos. A aplicação de $150+150 \mathrm{mg} \cdot \mathrm{L}^{-1}\left(\mathrm{BAP}+\mathrm{GA}_{3}\right)$ promoveu, ao final do período, maior massa dos frutos em comparação às demais e ao controle. Não foram observadas diferenças na produção de frutos, porém a concentração de $150+150 \mathrm{mg} \cdot \mathrm{L}^{-1}$ de $\mathrm{BAP}+\mathrm{GA}_{3}$ apresentou mais de $50 \%$ de frutos no padrão de comercialização tipo $\mathrm{n}^{\circ}$ 8. A aplicação exógena de $150+150 \mathrm{mg} \cdot \mathrm{L}^{-1}\left(\mathrm{BAP}+\mathrm{GA}_{3}\right.$ ), aos 15; 30 e 45 DAA, aumentou a massa, o diâmetro,o comprimento, a acidez e o percentual de frutos tipo $n^{\circ} 8$ da mangueira 'Tommy Atkins', mas não aumentou a produtividade.

Termos para indexação: Semiárido; 6-benzilaminopurina; Ácido giberélico; Mangifera indica L.

\footnotetext{
${ }^{1}$ Msc, Postgraduate Program in Agronomy (Irrigated Horticulture), Departament of Technology and Social Sciences, State University of Bahia, Juazeiro-BA, Brazil. E-mail: jbconsulagri@hotmail.com (ORCID:0000-0002-7609-8986); eng.p.ricardo@gmail.com (0RCID: 0000-0002-5062-8432)

${ }^{2}$ Agronomist student, Graduate Program in Agronomy, Departament of Technology and Social Sciences, State University of Bahia, JuazeiroBA, Brazil. E-mail: igordias_souza@hotmail.com ${ }^{\text {(ORCID:0000-0001-9716-0980); willianuneb2014.2@gmail.com }}{ }^{\text {(ORCID:0000-0002-5370-5894) }}$ gloriacaroline@live.com (ORCID: 0000-0001-6755-4794)

${ }^{3} \mathrm{PhD}$ Professor, Postgraduate Program in Agronomy (Irrigated Horticulture), Departament of Technology and Social Sciences, State University of Bahia, Juazeiro-BA, Brazil.E-mail: vribeiro@uneb.br (ORCID: 0000-0001-8093-3641)
} 


\section{Introduction}

Mango (Mangifera indica L.) has the third largest production among tropical fruits in the world, only behind banana and pineapple, being produced in more than 100 countries in tropical and subtropical regions (BALLY and DILLON, 2018). It stands out among the main fruit crops cultivated in Brazil, which is the seventh largest mango producer in the world, after India, China, Thailand, Indonesia, Pakistan and Mexico (FAOSTAT - FAO, 2020).

It is one of the most exported fruits in Brazil. In 2019, there was a record shipment, in terms of both volume, with about 221,913 thousand tons, a $30 \%$ increase compared to the previous year, and revenue, more than US\$227 million (ANUÁRIO, 2020). Mango cultivation in semi-arid regions is one of the main options for irrigated areas and the São Francisco Valley is one of the largest producers and exporters of this fruit, competing with its products in the international market (SOUZA et al., 2018). In the São Francisco Valley, in 2019 alone, there was a $25 \%$ growth in the cultivated area, according to a survey performed by the Center for Advanced Studies in Applied Economics (ANUÁRIO, 2020).

'Tommy Atkins' mango is the most cultivated in Brazil and has been increasingly accepted in the EU, particularly in northern European markets, probably as a result of the careful quality control (external appearance and degree of maturity) that has been performed by Brazilian producers in recent years (GÁLAN-SAÚCO, 2017).

Manipulation of mango production time through practices such as irrigation management, pruning and the use of plant regulators, associated with appropriate climatic conditions, has enabled mango producers in this region to schedule their production according to market demand, which has promoted advantages for the agribusiness of this fruit (MOUCO et al., 2012).

Different growth regulators are used to increase the size and quality of fruits in different species (CANLI; PEKTAS, 2015) and to increase their value and marketing (CANLI et al., 2015). Cytokinins and gibberellins are applied to many horticultural crops to increase fruit size (FLAISHMAN et al., 2001; OZGA; REINECKE, 2003).

Ideal fruiting of orchards can be maintained by the exogenous application of plant regulators. For example, exogenous application of auxin, gibberellins and cytokinins controls the percentage of fruit fall before harvest, leading to an increase in the total number of fruits per plant (KUMAR et al., 2014; OSUNA-ENCISO et al., 2019). In most fruits originated from cross-pollination, it helps prevent early abscission, replacing to some extent their normal endogenous production, besides directly increasing fruit size by stimulating cell division (BONS and KAUAR, 2019).
In this context, the objective of this study was to evaluate the effect of applications of cytokinins and gibberellins, $\mathrm{BAP}$ and $\mathrm{GA}_{3}$, on the growth, physicochemical characteristics and production of 'Tommy Atkins' mango fruits.

\section{Material and methods}

The experiment was conducted in a commercial orchard with 'Tommy Atkins' mango, grafted onto 'Coquinho' rootstock, planted in 2010 at spacing of $6 \mathrm{~m}$ x $4 \mathrm{~m}$, with a stand of 416 plants per hectare, located in the irrigated perimeter of Mandacaru, Juca Viana village (Agro Sol Farm), in Juazeiro-BA, Brazil, at the following geographical coordinates: $9^{\circ} 23^{\prime} 25.38^{\prime \prime}$ S latitude and $40^{\circ} 25^{\prime} 53.14^{\prime \prime} \mathrm{W}$ longitude.

The climate of the region according to Köppen's classification is Bwsh', which corresponds to a hot semi-arid climate, with limited rainfall regime, average annual precipitation of $540 \mathrm{~mm}$, historical annual average evapotranspiration ranging from 6.6 to $9.9 \mathrm{~mm} /$ day, with an average annual temperature of $26.3^{\circ} \mathrm{C}$, with a maximum of $31.4{ }^{\circ} \mathrm{C}$ and minimum of $20.9^{\circ} \mathrm{C}$ (TEIXEIRA, 2010; EMBRAPA, 2015).

The experiment was carried out between July and November 2019, in the phenological stages from flowering to harvest. Plants were selected according to size and level of flowering, and phytosanitary management, nutrition and weed control followed the usual practices of the farm.

\section{Solution preparation and spraying}

To calculate the amount of plant regulator used in each spray, proportional concentrations $\left(\mathrm{mg} . \mathrm{L}^{-1}\right)$ were prepared and each plant received 2 liters of solution per application with the respective concentrations. The substances were weighed on a precision scale and then diluted; BAP [6-benzylaminopurine] was diluted in hydrochloric acid $(0.1 \mathrm{~N} \mathrm{HCl})$ with a magnetic stirrer and gibberellin was diluted in water.

The applications were carried out using a backpack sprayer (Jacto $\left.{ }^{\circledR}\right)$, with cone nozzle, applying the solution on the whole plant. The solution $\mathrm{pH}$ was measured with a digital $\mathrm{pH}$ meter (Waterproof model) and, when necessary, $\mathrm{pH}$ reducers were used to correct the value up to 5.0 \pm 0.5 .

The spraying of the plant regulators was divided according to the fruit development stage. The treatments concerning the cytokinin isolated effects (Test 1 ) and the combination cytotinin+gibberellin (Test 2) were applied in the stage I where the flowering process occurs, markedly known as fruit set (SHAKYA and LAL, 2018); and in the stage II, marked by rapid cell divisions and by the seed formation and embryo development (SHAKYA and LAL, 2018). 
For the effect of the gibberellin (Test 3), plant regulator was applied in the stage III of the fruit development, in which ceases the cell division, the fruit growth in mainly attributed to the cellular increment occurs the size and final forms of the fruits and it is related a slightly size gain in the mango fruits when treated with $\mathrm{GA}_{3}$ (PÉREZ-BARRAZA et al., 2015; SHAKYA and LAL, 2018).

\section{Test 1 - Effect of cytokinin}

Mango plants were sprayed with five concentrations $\left(0,75,150,225\right.$ and 300 mg.L $\left.\mathrm{L}^{-1}\right)$ of BAP at 15 days after anthesis (DAA), at full flowering, and then again at 30 and 45 DAA, totaling three applications.

\section{Test 2 - Effect of cytokinin + gibberellin}

Mango plants were sprayed with five concentrations $\left(0,75,150,225\right.$ and $\left.300 \mathrm{mg} . \mathrm{L}^{-1}\right)$ of BAP [6-benzylaminopurine] and five concentrations $(0,75,150$, 225 and $\left.300 \mathrm{mg} . \mathrm{L}^{-1}\right)$ of $\mathrm{GA}_{3}$, both combined in the same solution, at $15 \mathrm{DAA}$, at full flowering, repeated at 30 and 45 DAA, totaling three applications.

\section{Test 3 - Effect of gibberellin}

Five different concentrations $(0,75,150,225$ and $300 \mathrm{mg} . \mathrm{L}^{-1}$ ) of $\mathrm{GA}_{3}$ were sprayed at $60 \mathrm{DAA}$, when mango fruit growth is resumed, and then repeated at 70 and 80 DAA, totaling three applications.

\section{Fruit development and growth analyses}

At 40 DAA, three fruits per plant were selected in four replicates, totaling 12 fruits per treatment (testsconcentrations) and 180 fruits in the entire experiment, and identified with colored ribbons. At $52 \mathrm{DAA}$, growth evaluations began by randomly measuring the fruits for their weight, diameter and length, nondestructively, at 7-day interval, until they reached physiological maturity, in a total of seven evaluations in Tests 1 and 2 and five evaluations in Test 3 . Fruit length and diameter were measured with a digital caliper (7VS Eda ${ }^{\circledR}$ model), and fruit weight was measured with a portable scale (SF-400 model).

\section{Physicochemical characterization of fruits}

At 105 DAA, a visual evaluation was performed, which showed a predominance of fruits type 8 (mango size sufficient to fill a commercial box with eight units) and maturity stage 2.5 . Thus, three fruits per plant (n plants $=4$ ), totaling 12 per treatment (tests-concentrations), were harvested, labeled and taken to the Olericulture
Laboratory of the Department of Technology and Social Sciences - DTSS/UNEB Campus III, where they were kept at temperature of $12( \pm 0.5)^{\circ} \mathrm{C}$ in a vertical freezer, for physicochemical characterization, which followed the analytical standards of Instituto Adolfo Lutz (2008).

Soluble solids contents were determined through the refractometry technique, using filtered juice from mango pulp slices, homogenized in domestic multiprocessor. The filtrate was read in a portable refractometer (103 Model), with reading within the range from 0 to $32^{\circ} \mathrm{Brix}$.

Total acidity was determined using a $10-\mathrm{mL}$ aliquot of juice, which received $40 \mathrm{~mL}$ of distilled water and three drops of alcoholic phenolphthalein at $1 \%$, followed by titration up to the turning point with $0.1 \mathrm{~N} \mathrm{NaOH}$ solution, previously standardized, and the results were expressed as \% citric acid (CARVALHO et al., 1990).

The $\mathrm{pH}$ was determined by directly immersing the $\mathrm{pH}$ meter electrode into the solution obtained by the extraction of fruit pulp homogenized with a domestic centrifuge. Reading was performed using a Hanna Instruments HI 8417 digital $\mathrm{pH}$ meter, calibrated with standard solution $\mathrm{pH} 4.0$ and 7.0. Fruit fresh weight was obtained by weighing on a precision scale $\left(\right.$ Filizola $\left.^{\circledR}\right)$.

\section{Experimental design}

The experimental design adopted was in randomized blocks, in a $3 \times 5$ factorial scheme, corresponding to three combinations of two regulators (BAP, $\mathrm{BAP}+\mathrm{GA}_{3}$ and $\left.\mathrm{GA}_{3}\right)$ and five concentrations $(0,75,150,225$ and 300 mg. $\mathrm{L}^{-1}$ ), with four replicates in each treatment, each unit consisting of one plant, with evaluations at 52, 59, 66, 73, 80,87 and 94 DAA for the tests with BAP and BAP + $\mathrm{GA}_{3}$ and at $66,73,80,87$ and 94 DAA for the tests with only $\mathrm{GA}_{3}$.

\section{Statistical analyses}

Fruit weight and length data were transformed to $\sqrt{x}$ and fruit diameter data were transformed to $x^{2}$, as they did not follow a normal distribution. After that, they were subjected to analysis of variance with repeated measures in time, through the GLIMMIX and PROC GLM (generalized linear mixed model) procedures of the statistical program SAS (SAS INSTITUTE, 2007). For the variables whose regression models did not fit with a satisfactory uniformity coefficient $\left(\mathrm{R}^{2}<0.7\right)$, their data were presented in terms of overall mean. 


\section{Results and Discussion}

\section{Fruit weight}

In the ANOVA by GLM, the effects of BAP concentrations on the increase of mango fruit weight, as well as the interaction between BAP application and days after application, showed significant responses $(\mathrm{p}<0.01)$, with $\mathrm{F}=9.90$ and $\mathrm{F}=3.58$, respectively.
The results for the effect of the interaction between treatments are presented in Figure 1A. From 52 to 66 DAA, all concentrations of cytokinin, in the form of BAP, showed the same trend of fruit development. The naturally occurring cytokinins, are derived from the adenina, relatively simple and modified on the nitrogen atom in the position 6 of the six-membered heterocycle, and promote not only the cell division, but also the cell expansion, playing a crucial role in the control of several processes in the growth and plants development, including the increment of the cell volume and development of fruits and seeds (JAMESON; SONG, 2016).

BAP

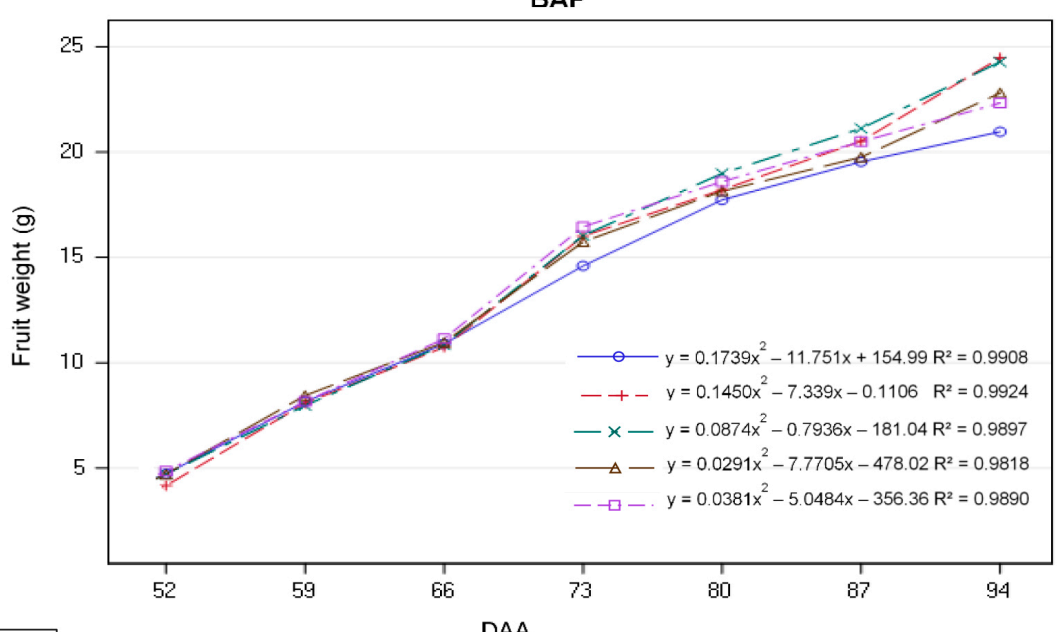

A

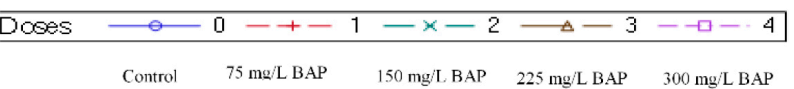

$\mathrm{BAP}+\mathrm{GA}_{2}$

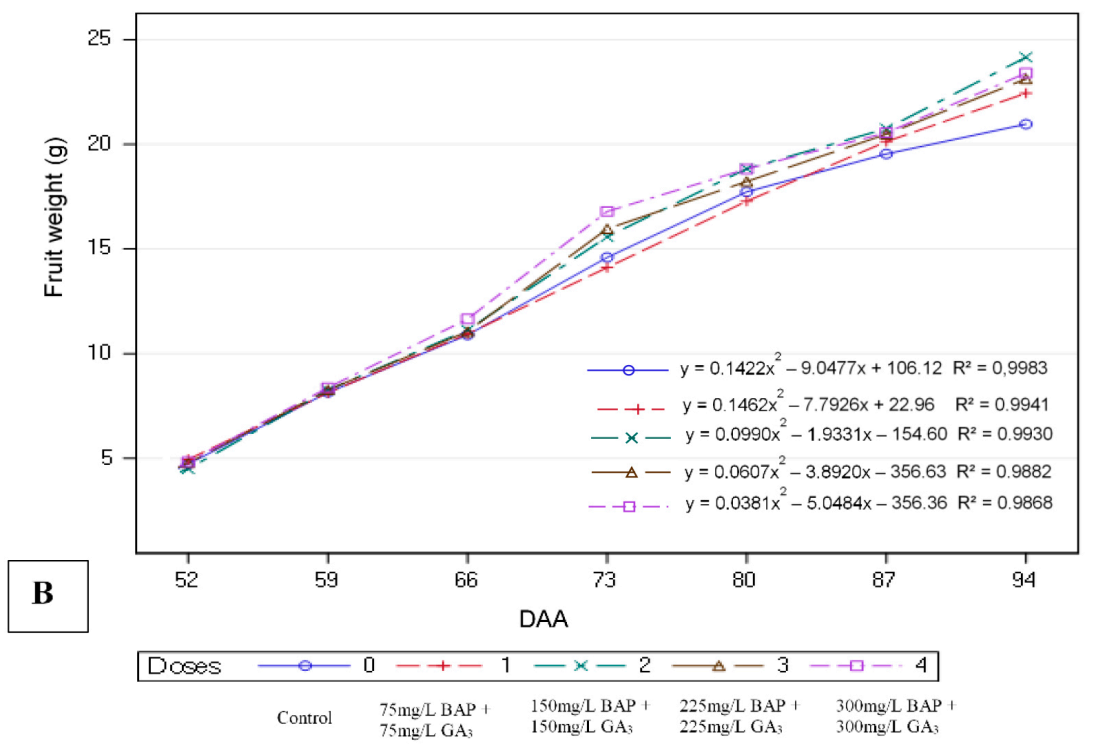

Figure 1. Evolution of the weight of 'Tommy Atkins' mango fruit, throughout its development stage, from 45 days after anthesis (DAA), Juazeiro-BA. A=Application of BAP; $\mathrm{B}=$ Application of BAP $+\mathrm{GA}_{3}$. Data transformed to $\sqrt{ } x$. 
Between 66 and 73 DAA, there was an increasing trend in fruit weight, demonstrated by a 2 nd-order polynomial equation, showing a higher growth peak in this period. In the same period, fruits under exogenous application of BAP (concentrations 1,2,3 and 4) distanced from the control treatment (concentration 0). Thus, the cumulative effect of the three BAP applications performed at 15,30 and 45 DAA on the growth of mango fruits was only noted from 66 DAA.

This can be explained by the probable by the increase in cells number in the fruit, since in many fruit trees, the production of cells before the flowering and immediately after the fertilization, is the first factor that drives the initial increment of the fruit (JOHNSON et al., 2011). Still, results show that the application of cytokinins is fundamental in the flowering time to induce greater celular division and, therefore, greater number of cells in the mango tree (PÉREZ-BARRAZA et al., 2017). Generally, a rapid increment in the levels of cytokinin (14-21 days after fertilization) correspond to a period of intense cell division in the pericarp and endosperm, and the levels in crease again after 35 days from the fertilization, peaking between 42 and 70 days of growth (RAM, 1992). This way, the elevated quantity of cells promoted by the cytokinin might be directly related to the size of the mango fruit observed in this present work (PÉREZ-BARRAZA et al., 2017).

The treatment that did not receive exogenous application of cytokinin (control) remained with lower development rates from 66 days, compared to those which received exogenous cytokinin, indicating effect of the concentrations. Such increase in the size of treated fruits, compared to the control, was also observed in kiwi fruits, for which the application at 20 days after full flowering (DAF) of CPPU (cytokinin) increased fruit size at harvest and, with 10 days of application, treated fruits already had larger volume and continued to grow at a higher rate compared to untreated fruits (AINALIDOU et al., 2016).

The significant effect of $\mathrm{BAP}+\mathrm{GA}_{3}$ applications at different concentrations on the increment of the weight of 'Tommy Atkins' fruits was observed through the ANOVA with repeated measures. There was interaction between concentrations and days after application with $\mathrm{F}=1.60$. In this interaction, as observed for the application of BAP, from 52 to 66 DAA, all treatments had the same trends of linear fruit growth (Figure 1B), with no difference between concentrations. Individually, any of these hormones can only initiate the fruit development in a certain average; however, studies verified that its application combined induces the normal growth of the fruits, even in the absence of fertilization (KUMAR et al., 2014).

From 66 DAA, the application of $300 \mathrm{mg} \cdot \mathrm{L}^{-1} \mathrm{BAP}+$ $300 \mathrm{mg} . \mathrm{L}^{-1} \mathrm{GA}_{3}$ (concentration 4) led to greater increments in fruit weight, compared to the other treatments, because it promoted a higher rate of development, confirmed by the higher growth rate between 66 and 77 DAA (Figure 1B). In the same interval, fruits with exogenous application of 150 mg. $\mathrm{L}^{-1} \mathrm{BAP}+150 \mathrm{mg} \cdot \mathrm{L}^{-1} \mathrm{GA}_{3}$ (concentration 2) and 225 mg. $\mathrm{L}^{-1} \mathrm{BAP}+225 \mathrm{mg} . \mathrm{L}^{-1} \mathrm{GA}_{3}$ (concentration 3 ) followed the same trend observed for the concentration 4 , but with lower intensity (Figure 1B). The same was reported by Pérez-Barraza et al. (2015) in 'Ataulfo' mango, where the positive action of the two regulators in stage III of fruit growth was confirmed, promoting larger size, probably due to their action on cell elongation. According to the authors, the effect of $\mathrm{GA}_{3}$ (gibberellin) is increased by TDZ (cytokinin) or by an interrelationship between these two regulators.

However, the development rate of fruits under concentration 3 (225 mg.L.- $\left.\mathrm{L}^{-1}\right)$ decreased from 73 DAA, to the point that concentrations 2 and 4 became equal to concentration 3 at $87 \mathrm{DAA}$, in terms of fruit weight, and at the end of the evaluation period the concentration 2 (150 mg.L. $\mathrm{L}^{-1} \mathrm{BAP}+150 \mathrm{mg} \cdot \mathrm{L}^{-1} \mathrm{GA}_{3}$ ) was superior to the others. Fruits treated with $75 \mathrm{mg} . \mathrm{L}^{-1} \mathrm{BAP}+75 \mathrm{mg} \cdot \mathrm{L}^{-1}$ $\mathrm{GA}_{3}$ (concentration 1) and fruits of the control treatment (concentration 0) had similar weight accumulation, but the control treatment was superior to the concentration 1, from 66 DAA.

The accumulated effect of the three BAP + GA applications at concentration 1 was only noted at 87 DAA, when the growth curve is higher, while the curve of the control treatment decreased, ending at 94 DAA, which showed the benefit of the application. Corroborating the present study, Sasaki and Utsunomiy (2002) observed an increase in the growth of 'Irwan' mango fruits treated with the combination of CPPU and $\mathrm{GA}_{3}$, but this effect was only observed when the application was performed from the end of the physiological fruit drop, indicating that the efficacy of CPPU $+\mathrm{GA}_{3}$ application varies with fruit growth stage.

According to the ANOVA, exogenous application of gibberellin $\left(\mathrm{GA}_{3}\right)$ at 60,70 and 80 DAA had significant simple effects for the factors concentrations and days after application. Unlike treatments with $\mathrm{BAP}$ and $\mathrm{BAP}+\mathrm{GA}_{3}$, there was no interaction between concentrations and for days after application ( $p>0.05$ ), which may be due to the later application of GA3 in phase III of fruit development, wherein the gibberellin content increases with the growth rate of the mango fruit and seed, decreasing after 42 days (RAM, 1992).

The gibberellin is a member of a group of naturally occurring tetracyclic diterpenoid carboxylic acids, and many gibberellins have biological activity when applied to plants due to the metabolism of the active forms by the plant (HEDDEN, 2017). Promoting the growth and the cell division, the gibberellin stimulates a cell elongation (longitudinal growth), mainly internodes elongation and fruits development, and the cell expansion throughout the induction of hydrolytic enzymes (TAIZ; ZEIGER, 2017; RADEMACHER, 2016). 
The cumulative effect of $\mathrm{GA}_{3}$ applications on fruit weight after mango growth resumption was observed at all concentrations, which differed significantly from the control (Figure 2), with no difference between the concentrations tested, regardless of the days after application, which indicates that exogenous application of $\mathrm{GA}_{3}$ at 60,70 and $80 \mathrm{DAA}$, from $75 \mathrm{mg}$. $\mathrm{L}^{-1}$, was sufficient to promote the significant increase in the weight of 'Tommy Atkins' fruits. The $\mathrm{GA}_{3}$ is widely used in different species to enhance the size of the fruits, especially the parthenocarpic fruits (HAJAM et al., 2018). In a mango tree, the use of $\mathrm{GA}_{3}$ reflected in one increment between $10 \%$ of the mass of the fruit in relation to the control (PÉREZ-BARRAZA et al., 2015).

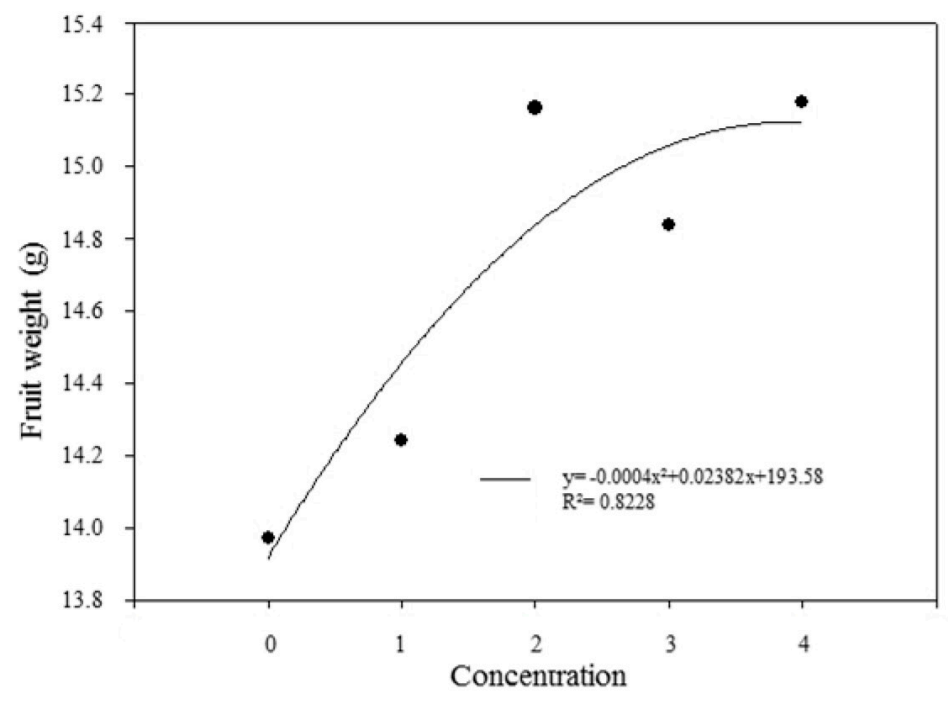

Figure 2. Weight of 'Tommy Atkins' mango fruits subjected to different $\mathrm{GA}_{3}$ concentrations. Concentration 0: control; 1: $75 \mathrm{mg} . \mathrm{L}^{-1} ; 2: 150 \mathrm{mg} . \mathrm{L}^{-1} ; 3: 225 \mathrm{mg} . \mathrm{L}^{-1} ; 4: 300 \mathrm{mg} . \mathrm{L}^{-1}$. Data transformed to $\sqrt{ } x$.

The increment of weight, regardless of concentration, was described by a second-degree model with $\mathrm{R}^{2}$ equal to 0.9923 (Figure 3). At the beginning of the evaluations, in the period between 66 and 73 DAA, there was a more significant increment of weight in a shorter period of time, which might be related to this rate of cell expansion nearer to the physiological maturity.

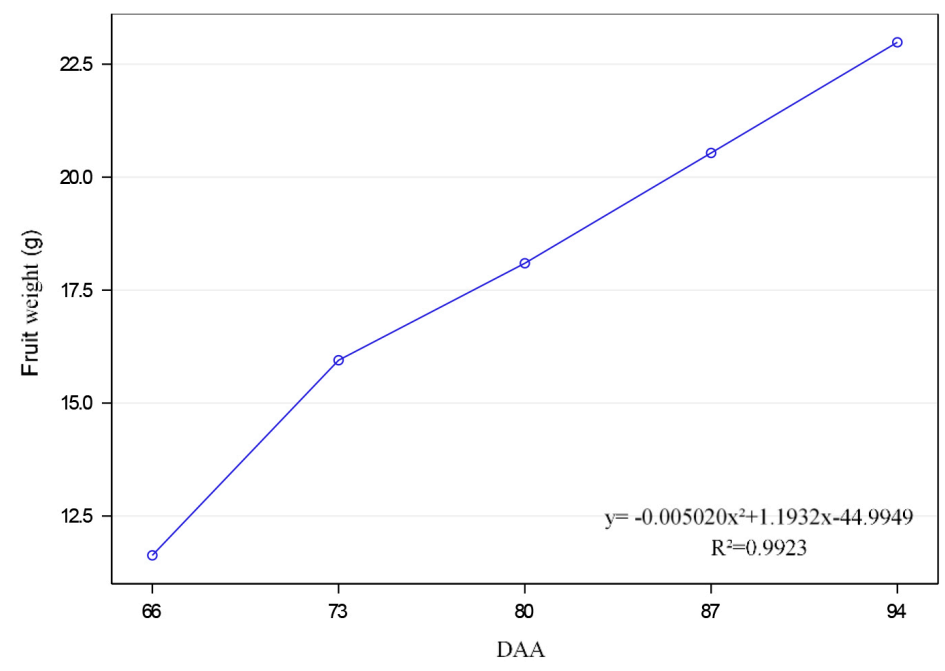

Figure 3. Evolution of the weight of 'Tommy Atkins' mango fruit, with $\mathrm{GA}_{3}$, throughout its development stage, from 66 days after anthesis (DAA). Data transformed to $\sqrt{ } x$. 
This behavior suggests that the effect of $\mathrm{GA}_{3}$ applied at 60 DAA is stronger in this period and that basically only one application was sufficient to promote this peak growth. In this stage III (45-90 DAA), Where the fruits achieve the maximum of size, one unique application of $\mathrm{GA}_{3}$ in the 60 DAA was enough to differentiate the mangoes 'Ataulfo' treated with the bioregulator from those not treated (PÉREZ-BARRAZA et al., 2015), corroborating with our results. However, after 73 DAA, the increment of weight continued until the end of the evaluations (94 DAA), but at lower and constant rates.

\section{Fruit length}

Regarding fruit length, the ANOVA with repeated measures in time revealed a significant difference for BAP concentrations $[\mathrm{F}=9.79 ; \mathrm{p}<0.0001]$ and days after application $[\mathrm{F}=1360.13 ; \mathrm{p}>0.0001]$. However, no significant interaction was observed $(p>0.05)$ between concentrations and days after application.

For the concentrations, the regression model did not fit with a satisfactory uniformity coefficient $\left(\mathrm{R}^{2}<0.7\right)$. Thus, the data were presented with overall means. For BAP, the concentration of $150 \mathrm{mg} \cdot \mathrm{L}^{-1}$ had the highest mean, while the treatment with $225 \mathrm{mg} \cdot \mathrm{L}^{-1}$ and the control treatment had the lowest means. The means obtained with the concentrations of $75 \mathrm{mg} . \mathrm{L}^{-1}$ and $300 \mathrm{mg} . \mathrm{L}^{-1}$ were the closest ones to the overall mean (Figure 4A).

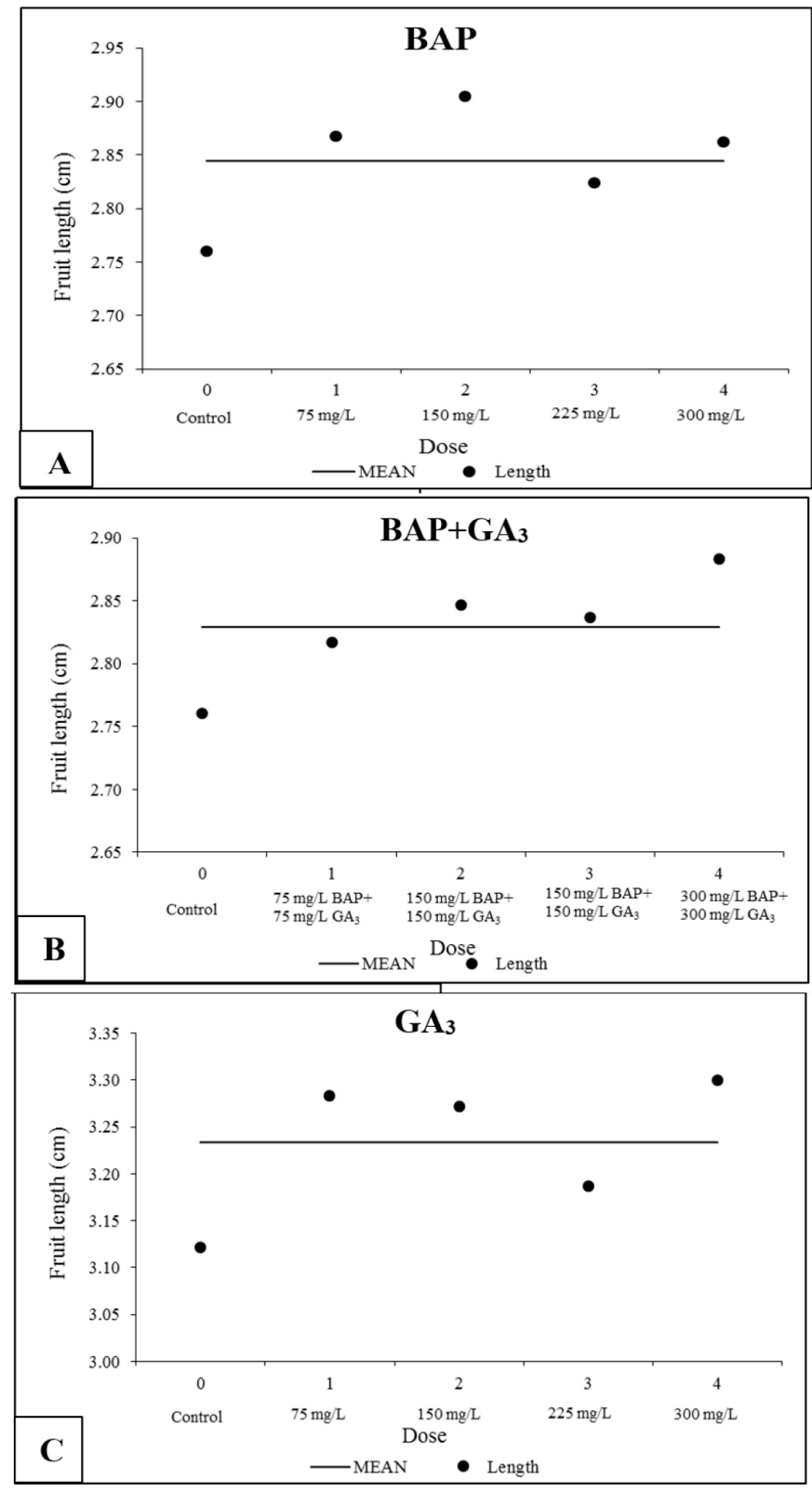

Figure 4. Length of 'Tommy Atkins' mango fruits subjected to different concentrations of BAP, BAP+GA and $\mathrm{GA}_{3}$. $\mathrm{A}=$ Application of $\mathrm{BAP} ; \mathrm{B}=$ Application of $\mathrm{BAP}+\mathrm{GA}_{3} ; \mathrm{C}=$ Application of $\mathrm{GA}_{3}$. Data transformed to $\sqrt{ } x$. 
For the days after anthesis, fruit length in the treatments with BAP showed a quadratic development (Figure 5A). A progressive increase was observed from 52 DAA to 73 DAA, being responsible in this period for basically all the growth in length of 'Tommy Atkins' mango fruits. After this period, there was a stabilization at 80 DAA without significant increase in length, demonstrated by a 2 nd-order polynomial equation.
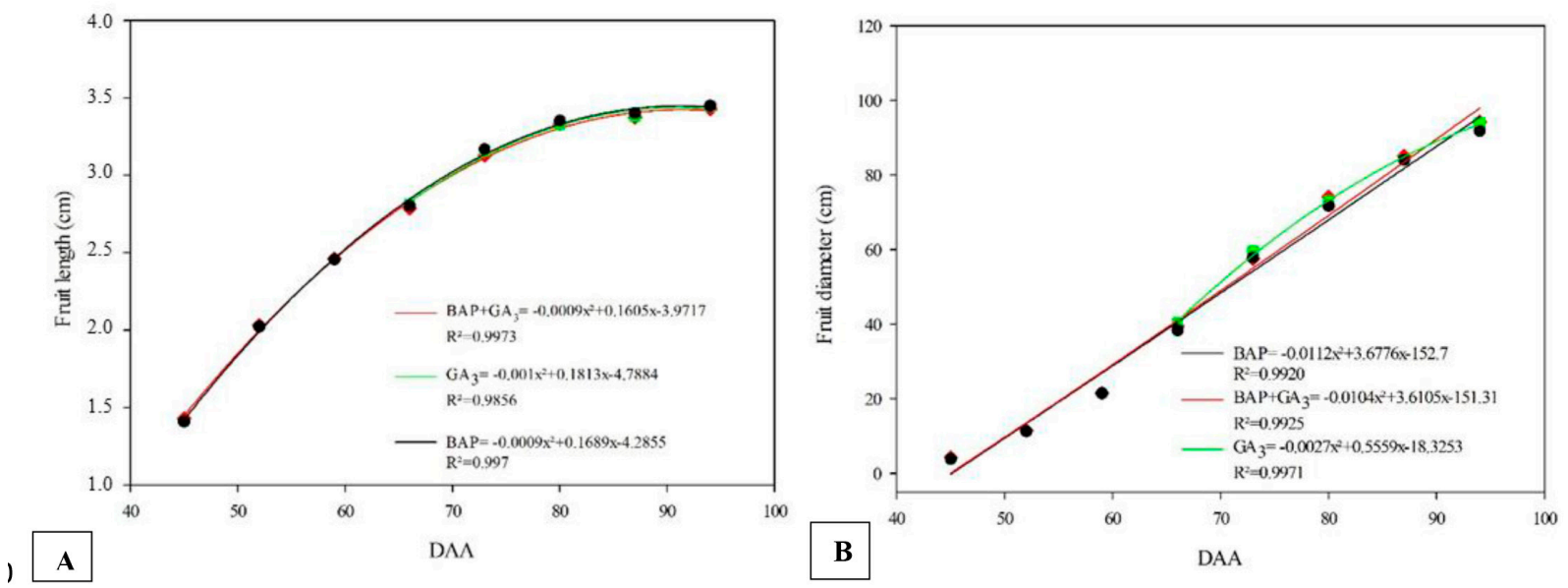

Figure 5. Evolution of the growth of 'Tommy Atkins' mango fruit, throughout its development stage, from 52 days after anthesis (DAA). $\mathrm{A}=$ Length; $\mathrm{B}=$ Diameter. Data transformed to $\sqrt{x}$ and $x^{2}$, respectively.

For BAP $+\mathrm{GA}_{3}$ concentrations, the ANOVA showed significant difference for concentrations $[\mathrm{F}=6.54$; $\mathrm{p}<0.0001]$ and for the days after application $[\mathrm{F}=178.18$; $\mathrm{p}<0.0001]$, with no significant interaction $(\mathrm{p}>0.05)$ between concentrations and days after application.

$\mathrm{BAP}+\mathrm{GA}_{3}$ concentrations ranging from $150 \mathrm{mg} . \mathrm{L}^{-}$ ${ }^{1}$ to $300 \mathrm{mg} . \mathrm{L}^{-1}$ (concentrations 2,3 and 4 ) induced an increase in fruit length, leading to higher mean compared to that of the treatment without exogenous application of the regulator (control), showing a significant longitudinal increase in 'Tommy Atkins' mango fruits, regardless of the time evaluated (Figure 4B). Fruits of plants sprayed with $75 \mathrm{mg} . \mathrm{L}^{-1} \mathrm{BAP}+75 \mathrm{mg} \cdot \mathrm{L}^{-1} \mathrm{GA}_{3}$ had a value below the overall mean, equaling the control, which suggests the inefficiency of this concentration for fruit growth.

It can be verified that the variation in fruit length, for the four concentrations of $\mathrm{BAP}+\mathrm{GA}_{3}$ and control, can be significantly explained by a 2nd-order polynomial equation, with coefficients of determination equal to $99.41 \%$ (Figure $5 \mathrm{~A}$ ). As observed in the test where only cytokinin (BAP) was applied, the curve showed a behavior with interruption of longitudinal growth from 80 DAA, so the increments were more significant between 52 and 73 DAA.

In relation to the treatment with $\mathrm{GA}_{3}$, the ANOVA with repeated measures in time showed significant differences for concentrations $[\mathrm{F}=9.95 ; \mathrm{p}<0.0001]$ and days after application $[\mathrm{F}=105.05 ; \mathrm{p}>0.0001]$. However, no significant interaction was observed $(p>0.05)$ between concentrations and days after application.

For the $\mathrm{GA}_{3}$ concentrations, the application of 300
mg.L.- $\mathrm{GA}_{3}$ (concentration 4) led to the highest mean, whereas the concentrations of $225 \mathrm{mg} . \mathrm{L}^{-1}$ and control (concentrations 3 and 0 , respectively) had the lowest mean, but the mean obtained with the application of 75 and 150 mg.L $\mathrm{L}^{-1} \mathrm{GA}_{3}$ (concentrations 1 and 2) was above the overall mean (Figure 4). For the mango cv. 'Ataulfo', single application of $50 \mathrm{mg} . \mathrm{L}^{-1} \mathrm{GA}_{3}$ at $60 \mathrm{DAA}$, which corresponds to the development stage III, led to fruits with longer length compared to those of the control (PÉREZBARRAZA et al., 2015), confirming the efficiency of the exogenous application of $\mathrm{GA}_{3}$ at lower concentrations.

The longitudinal growth of the fruits, as in the treatments with $\mathrm{BAP}$ and $\mathrm{BAP}+\mathrm{GA}_{3}$, was significantly described by a 2nd-order polynomial model, with a high coefficient of determination (Figure 5A). As for the increase in fruit weight, a higher and faster growth occurred between 66 and 73 DAA, suggesting that this behavior was caused by the first application (60 DAA) and that these noticeable effects occur earlier with $\mathrm{GA}_{3}$ than with $\mathrm{BAP}$ and $\mathrm{BAP}+\mathrm{GA}_{3}$. However, the fruit continued to grow in size until the end of the evaluations.

\section{Fruit diameter}

In the evaluation of fruit diameter under BAP application, the ANOVA showed no significance for the different concentrations $[\mathrm{F}=1.42 ; \mathrm{p}=0.23]$, as well as for the interaction between concentrations and days after application $[\mathrm{F}=0.88 ; \mathrm{p}=0.64]$. Only the time factor (days after application) had a significant effect $(p<0.0001)$, which was already expected to occur, because the fruits naturally grow in size during their development. 
As observed for fruit length, fruit diameter showed a quadratic development, regardless of BAP concentrations, with a high coefficient of determination (Figure 5B). The highest rate of increase in diameter occurred between 59 and 73 DAA. However, unlike the results for fruit length presented in Figure 5, there was no trend of stabilization of growth in diameter at 80 DAA. Thus, 'Tommy Atkins' mango fruits continued to grow in volume transversely from 80 to 94 DAA (Figure 5B), even after longitudinal growth stopped (Figure 5), but at lower rates than in the period from 66 to 73 DAA, which characterizes the stage of filling of the mango fruits.

These results corroborate those reported by Lucena et al. (2007), who studied the growth curve of the mango cv. 'Tommy Atkins', in the São Francisco Valley, Petrolina, PE, Brazil, and found that the longitudinal, ventral and cross diameters showed a quadratic fit as a function of the variation in time. However, unlike the present study, the fruits grew in size until the 10th week after anthesis (WAA), when the length was evaluated, and until the 11th WAA, when the ventral and cross diameters were evaluated. After this time, these characteristics remained virtually constant (LUCENA et al., 2007) and, in the present study, fruit diameter stopped increasing and fruit size continued to increase, showing that the application of bioregulators in young mango fruits promotes the continuity of the growth, mainly by the creation of demand water points and nutrients in the cells, that is, there is a mobilization of metabolites to the application sites, that expands the cells and increase the fruit size (SUMAN et al., 2017; KUMARI et al., 2018).

Regarding fruit diameter with $\mathrm{BAP}+\mathrm{GA}_{3}$, significant effects were observed for the different concentrations $[\mathrm{F}=6.05 ; \mathrm{p}=0.0002]$ and time (days after application) $[\mathrm{F}=6.05 ; \mathrm{p}<0.0001]$, but the interaction between concentrations and days after application was not significant.

According to the regression analysis, the largest mean diameter was observed at the concentration of 225 mg.L $\mathrm{L}^{-1} \mathrm{BAP}+225 \mathrm{mg} \cdot \mathrm{L}^{-1} \mathrm{GA}_{3}$ (concentration 3) (Figure $6 \mathrm{~B})$, regardless of the evaluation date, with a reduction from $300 \mathrm{mg} \cdot \mathrm{L}^{-1} \mathrm{BAP}+300 \mathrm{mg} \cdot \mathrm{L}^{-1} \mathrm{GA}_{3}$ (concentration 4). The concentration of $75 \mathrm{mg} \cdot \mathrm{L}^{-1} \mathrm{BAP}+75 \mathrm{mg} \cdot \mathrm{L}^{-1} \mathrm{GA}_{3}$ and the control treatment led to the lowest means (Figure 6B). Interactions of plant regulators based on cytokinins and gibberellins have been reported in the increase of size of 'Keitt' mango fruits when they are applied at pre-harvest, also improving the quality and post-harvest life of mango (OSUNA-ENCISO et al., 2019).

Fruit diameter showed a quadratic growth, regardless of $\mathrm{BAP}$ and $\mathrm{GA}_{3}$ concentrations, with a high coefficient of determination $\left(\mathrm{R}^{2}=0.9953\right)$, which points to an excellent fit of the model to the data (Figure 5B). From 52 to $59 \mathrm{DAA}$, the fruits showed a linear growth trend, but there was an increase in fruit diameter from 59 DAA, indicating that the largest gain in diameter occurred from 59 to 80 DAA.

Regarding the diameter of fruits treated with $\mathrm{GA}_{3}$, the ANOVA revealed significance for the effects of concentrations $[\mathrm{F}=5.94 ; \mathrm{p}=0.0003]$ and days after application (time) $[\mathrm{F}=224.13 ; \mathrm{p}<0.0001]$, but there was no satisfactory fit for the concentration. The interaction between the factors concentrations and days after application was significant $(\mathrm{p}>0.05)$.

Unlike the results found for fruit length, the concentration of $75 \mathrm{mg} . \mathrm{L}^{-1} \mathrm{GA}_{3}$ promoted the largest average fruit diameter, regardless of the time evaluated. The concentration of $225 \mathrm{mg} . \mathrm{L}^{-1}$ and the control (concentrations 3 and 0 , respectively) promoted average fruit diameter below the values of the other treatments (Figure 6C).

The data of fruit growth in diameter along the days after anthesis showed a quadratic behavior (Figure 5B), which was already observed in the other treatments (BAP and $\mathrm{BAP}+\mathrm{GA}_{3}$ ). The initial growth occurred in a soft and constant way, with no major inclination on the curve, which characterizes a peak of growth. Possibly, the effect of $\mathrm{GA}_{3}$ in this evaluated period is more prominent for longitudinal growth than for transverse growth.

\section{Chemical characterization of fruits and yield}

The mean values of soluble solids contents (SS) and hydrogen potential $(\mathrm{pH})$ in the fruits of the three tests with plant regulators in the cultivar 'Tommy Atkins' did not show significant differences at 5\% probability level.

Regarding fruit $\mathrm{pH}$, the same has been observed in studies aimed at increasing the size and quality of fruits of pear and sweet cherry cultivars with applications of benzyl adenine (BAP) and gibberellin $\left(\mathrm{GA}_{4+7}\right)$, and no significant differences were observed between the control and the treated fruits (CANLI; PEKTAS, 2015; CANLI et al., 2015).

Mango is considered an acidic fruit and most cultivars have $\mathrm{pH}$ values below 6.0 (SANTOS et al., 2015). In general, the $\mathrm{pH}$ of mango fruits subjected to the different regulators varied on average between 2.28 and 3.52 (Table 1), being within the standard reported in the literature. For example, Costa et al. (2017) found $\mathrm{pH}$ values between 3.31 and 4.34 along the maturation of 'Tommy Atkins' mango fruits. 

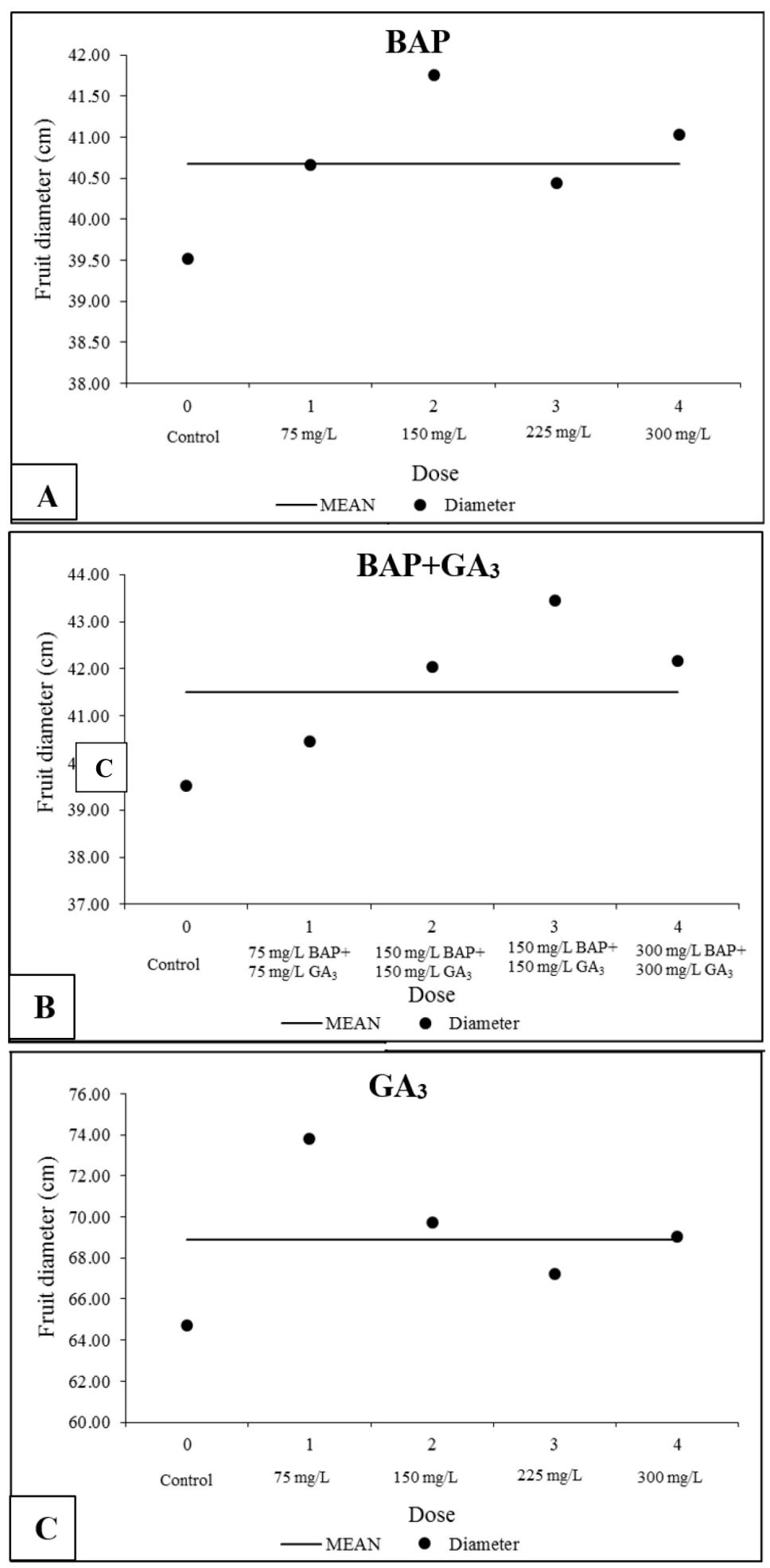

Figure 6. Diameter of 'Tommy Atkins' mango fruits subjected to different concentrations of BAP+GA $\mathrm{G}_{3}$ and $\mathrm{GA}_{3}$. A $=$ Application of $\mathrm{BAP} ; \mathrm{B}=$ Application of $\mathrm{BAP}+\mathrm{GA}_{3} ; \mathrm{C}=$ Application of $\mathrm{GA}_{3}$. Data transformed to $x^{2}$. 
Table 1. pH, soluble solids content (SS), titratable acidity (TA) and SS/TA ratio in ripe 'Tommy Atkins' mango fruits, produced under exogenous application of $\mathrm{BAP}, \mathrm{BAP}+\mathrm{GA}_{3}$, and $\mathrm{GA}_{3}$ as a function of five concentrations, Juazeiro, BA, 2020.

\begin{tabular}{|c|c|c|c|c|}
\hline & $\mathrm{pH}$ & SS ( ${ }^{\circ}$ Brix) & TA (\% citric acid) & SS/TA ratio \\
\hline \multicolumn{5}{|l|}{$\overline{\mathrm{BAP}}\left(\mathrm{mg} . \mathrm{L}^{-1}\right)$} \\
\hline 0 & 3.39 & 7.94 & 0.716 & 11.93 \\
\hline 75 & 3.33 & 7.89 & 0.761 & 11.62 \\
\hline 150 & 3.52 & 8.33 & 0.881 & 10.02 \\
\hline 225 & 2.28 & 8.54 & 0.756 & 11.91 \\
\hline 300 & 3.42 & 8.55 & 0.749 & 12.61 \\
\hline \multicolumn{5}{|c|}{$\mathbf{B A P}+\mathrm{GA}_{3}\left(\mathrm{mg} \cdot \mathrm{L}^{-1}\right)$} \\
\hline 0 & 3.40 & 7.94 & $-*$ & $-*$ \\
\hline $75+75$ & 3.42 & 7.32 & - & - \\
\hline $150+150$ & 3.39 & 8.27 & - & - \\
\hline $225+225$ & 3.34 & 7.17 & - & - \\
\hline $300+300$ & 3.39 & 7.07 & - & - \\
\hline \multicolumn{5}{|l|}{$\mathrm{GA}_{3}\left(\mathrm{mg} \cdot \mathrm{L}^{-1}\right)$} \\
\hline 0 & 3.40 & 7.94 & 0.717 & 11.93 \\
\hline 75 & 3.49 & 7.83 & 0.932 & 9.25 \\
\hline 150 & 3.38 & 7.04 & 0.804 & 9.49 \\
\hline 225 & 3.35 & 7.15 & 0.813 & 9.76 \\
\hline 300 & 3.40 & 7.17 & 0.950 & 8.38 \\
\hline
\end{tabular}

*The data were subjected to regression analysis and are shown in Figure 7.

Differently, in another study with sweet cherry, the effect of treatments with BAP and $\mathrm{GA}_{4+7}$ on fruit SS was complex, and only $50 \mathrm{ppm}$ of BAP led to the production of fruits with higher content than that found in the control (CANLI et al., 2015). In the present study, the range of SS content recorded was between 7.07 and $8.55^{\circ}$ Brix (Table 1). Although not significant, the SS values were within the harvest standard for foreign market, which is between 7 and $8^{\circ}$ Brix (ASSIS et al., 2002; FILGUEIRAS et al., 2001; LIMA et al., 2009).

This result is remarkable because the SS contents remained within the harvest standard even with the significant increase in fruit fresh weight, length and diameter, as seen in the previous topics, indicating that the regulators do not seem to interfere with the accumulation or reduction of carbohydrates and that there is no dilution of the solutes with the increase in length and diameter.

Regarding titratable acidity (TA) and SS/TA ratio, the analysis of variance showed significant effect only of the combined concentrations of BAP $+\mathrm{GA}_{3}(\mathrm{p}<0.05)$; in the other tests the effects were not significant.

The TA data were described by an increasing linear regression model, with a coefficient of determination $>0.8$ (Figure $7 \mathrm{~A})$. Thus, the highest acidity $(1.15 \%$ citric acid) was recorded in the treatment with $300+300 \mathrm{mg} . \mathrm{L}^{-1}$ BAP $+\mathrm{GA}_{3}$, while the treatment with $75+75 \mathrm{mg} \cdot \mathrm{L}^{-1} \mathrm{BAP}$ and GA led to the lowest acidity $(0.67 \%$ citric acid $)$.
Degradation of organic acids is a common event during fruit growth and maturation and may be associated with changes in other compounds, such as carbohydrates (LIMA et al., 2009). Studies conducted with the same cultivar in the São Francisco Valley found final TA values between 0.7 and $0.9 \%$ citric acid, which are close to those presented in this study (LIMA et al., 2009; COSTA et al., 2017), except for treatments with $225+225$ and $300+$ $300 \mathrm{mg} . \mathrm{L}^{-1} \mathrm{BAP}+\mathrm{GA}_{3}$, which showed a slight increase in acidity, although the values are still within the standard recommended for harvest, which is below $1.3 \%$, so these treatments may induce some delay in ripening.

The variation in SS/TA ratio for the four BAP + $\mathrm{GA}_{3}$ concentrations and the control can be explained by a decreasing 1st-order polynomial model, with $\mathrm{R}^{2}>0.97$. The SS/TA ratio is the most indicated index for evaluating palatability and maturation, as it gives an idea of the balance between sugars and acidity (BOMFIM et al., 2009; CHITARRA ;CHITARRA, 2005). Thus, as the SS/ TA ratio results from the two main chemical parameters of the fruits, the concentration of $300+300 \mathrm{mg} . \mathrm{L}^{-1} \mathrm{BAP}$ $+\mathrm{GA}_{3}$ led to the lowest ratio, whereas the highest SS/TA ratios were found in mango fruits of the control treatment and under $75+75 \mathrm{mg} \cdot \mathrm{L}^{-1} \mathrm{BAP}+\mathrm{GA}_{3}$, suggesting the effect of the regulators mainly on acidity. 
Regarding mango yield, production of fruits per plant and percentage of fruits type 8 , no significant differences were observed $(\mathrm{p}>0.05)$ between treatments, and their mean values are presented in Table 2. Plants treated with BAP at concentrations of 75 and $150 \mathrm{mg} . \mathrm{L}^{-1}$, $\mathrm{BAP}+\mathrm{GA}_{3}$ at concentrations of 150 and $225 \mathrm{mg} . \mathrm{L}^{-1}$ and

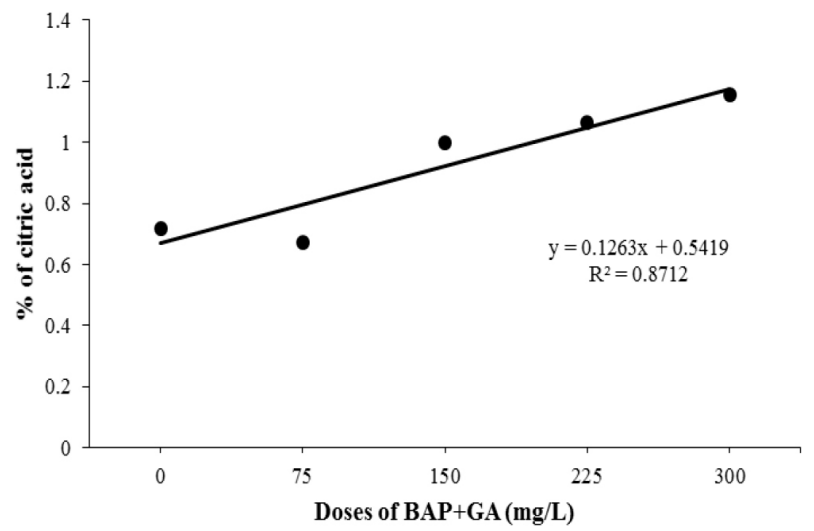

$\mathrm{GA}_{3}$ at concentration of $75 \mathrm{mg} . \mathrm{L}^{-1}$ had more than $50 \%$ of the fruits classified as type 8 (mango size sufficient to fill a commercial box with eight units), approximately 500 $\mathrm{g}$, which is the most preferable by producers due to the better economic return (Table 2).

Figure 7. Titratable acidity (TA) and SS/TA ratio in ripe 'Tommy Atkins' mango fruits, produced under exogenous application of BAP and GA3 as a function of five concentrations, Juazeiro, BA, 2020.

Table 2. Production and yield of 'Tommy Atkins' mango produced under exogenous application of BAP and GA 3 as a function of five concentrations, Juazeiro, BA, 2020.

\begin{tabular}{|c|c|c|c|c|}
\hline $\begin{array}{l}\text { Treatments } \\
\left(\mathrm{mg.L} \mathbf{L}^{-1}\right)\end{array}$ & $\begin{array}{c}\text { Fruit Weight/ } \\
\text { Plant }^{\mathrm{NS}}\end{array}$ & $\begin{array}{l}\text { Av. Number of } \\
\text { Fruits/Plant }{ }^{\mathrm{NS}}\end{array}$ & $\begin{array}{c}\text { Yield } \\
(\mathrm{t} / \mathrm{ha})^{\mathrm{NS}}\end{array}$ & $\begin{array}{l}\text { \% Fruits type } \\
n^{0} 8\end{array}$ \\
\hline \multicolumn{5}{|l|}{ BAP } \\
\hline 0 & 43.5 & 60.8 & 18.1 & 37.26 \\
\hline 75 & 38.5 & 48.8 & 16.0 & 63.86 \\
\hline 150 & 33.3 & 47.8 & 13.9 & 50.63 \\
\hline 225 & 50.3 & 74.0 & 20.9 & 26.11 \\
\hline 300 & 46.0 & 67.0 & 19.2 & 32.28 \\
\hline \multicolumn{5}{|l|}{$\mathbf{B A P}+\mathbf{G A}_{3}$} \\
\hline 0 & 43.5 & 60.8 & 18.1 & 37.26 \\
\hline 75 & 53.3 & 78.3 & 22.2 & 43.91 \\
\hline 150 & 36.5 & 49.3 & 15.2 & 57.57 \\
\hline 225 & 47.3 & 62.8 & 19.7 & 51.15 \\
\hline 300 & 53.3 & 73.5 & 22.2 & 40.43 \\
\hline \multicolumn{5}{|l|}{$\mathbf{G A}_{3}$} \\
\hline 0 & 43.5 & 60.8 & 18.1 & 37.26 \\
\hline 75 & 47.5 & 67.5 & 19.8 & 55.29 \\
\hline 150 & 54.3 & 85.0 & 22.6 & 28.20 \\
\hline 225 & 42.3 & 60.5 & 17.6 & 36.24 \\
\hline 300 & 53.0 & 75.3 & 22.1 & 41.13 \\
\hline
\end{tabular}

Ns: Not significant 
In theory, the absence of significant difference in the yield of plants treated with plant regulators and control plants is a satisfactory result, because there was an improvement in the physicochemical characteristics of the fruits that received exogenous application, as presented and discussed in the previous topics, without significant negative influence on yield as seen in another study with pear fruit subjected to $100 \mathrm{ppm}$ of Bain which had an increasement of the size of the fruit without significant negative influence on yelding (CANLI; PEKTAS, 2015). Furthermore, Canli and Pektas (2015) found heavy reductions in yield of the low cropping pear 'Acka' When were sprayed combinations cytokinin and gibberellin in 25 and $50 \mathrm{ppm}$, despite promoted the major size of the fruit. Differently, in our study the combination of these two plant growth regulators has not drastically reduced yield, indicating to be a variable effect among the species. Therefore, the exogenous application must to be justified by the importance of the quantity of mango fruits type box 8 (more commercial size) and for the potential market, this latter emphasized by Canli and Pektas (2015).

However, the plants used in this study were subjected to the standard phytosanitary management of the farm, and a high incidence of fruit flies was found in the area, resulting in premature fruit fall, which may have negatively influenced the evaluation of yield.

\section{Conclusions}

Application of cytokinins and gibberellins was effective to promote the growth of 'Tommy Atkins' mango fruits in terms of fresh weight accumulation, length and diameter, with accentuated growth between 52 and 75 DAA for all treatments evaluated;

Combined application of BAP and $\mathrm{GA}_{3}$ promoted higher acidity of the fruits, and fruit growth and quality were optimized with applications of $150 \mathrm{mg} . \mathrm{L}^{-1}$ at 15,30 and 45 DAA, but the yield was not changed.

\section{References}

AINALIDOU, A.; TANOU, G.; BELGHAZI, M.; SAMIOTAKI, M.; DIAMANTIDIS, G.; MALASSIOTIS, A.; KARAMANOLI, K. Integrated analysis of metabolites and proteins reveal aspects of the tissue specific function of synthetic cytokinin in kiwifruit development and ripening. Journal of Proteomics, Amsterdam, v.143, p.318-333, 2016.

ANUÁRIO BRASILEIRO DA FRUTICULTURA. Santa Cruz do Sul: Editora Gazeta Santa Cruz, 2020. 51 p.

ASSIS, J.S.; FETT, M.S.; LIMA, M.A.C.; CANTILANO, R.F.F.; SELF, G. Elaboração e difusão das normas da produção integrada da manga no Brasil: colheita e pós-colheita. Petrolina: Embrapa, 2002.

BALLY, I.S.E.; DILLON, N.L. Mango (Mangifera indica L.) Breeding. In: Al-KHAYRI J.; JAIN S.; JOHNSON D. (ed.). Advances in plant breeding strategies: fruits. Dordrecht: Springer, 2018. p.811-896.

BOMFIM, M.P.; LIMA, G.P.P.; SÃO JOSÉ, A.R.; HOJOREBOUÇAS, T.N.; CHATZIVAGIANNIS, M.A.F.; SOUZA, I.V.B. Caracterização físico-química de manga cv Bourbon submetidas à aplicação de cloreto de cálcio na pós-colheita. Revista Iberoamericana de Tecnología Postcosecha, Hermosillo, v.10, n.1, p.26-35, 2009.

BONS, H.K.; KAUR, M. Role of plant growth regulators in improving fruit set, quality and yield of fruit crops: a review. The Journal of Horticultural Science and Biotechnology, London, v.95, n.2, p.137-146, 2019.

CANLI, F.A.; PEKTAS, M. Improving fruit size and quality of low yielding and small fruited pear cultivars with benzyladenine and gibberellin applications. European Journal of Horticultural Science, Stuttgart, v.80, n.3, p.103-108, 2015.

CANLI, F.A; PEKTAS, M.; ERCISLI, S. Benzyladenine and gibberellin applications improve fruit weight and delay maturity of sweet cherry. Erwerbs-Obstbau, Berlim, v.57, p.71-75, 2015.

CARVALHO，C.R.L.; CARVALHO，P.R.N. MANTOVANI, D.M.B.; MORAES, R.M. Análise química de alimentos. Campinas: ITAL, 1990. 12p.

CHITARRA, M.I.F.; CHITARRA, A.B. Pós-colheita de frutos e hortaliças: fisiologia e manuseio. Lavras: ESALFAEPE, 2005. 785p. 
COSTA, J.D.S.; FIGUEIREDO-NETO, A.; ALMEIDA, F.A.C.; COSTA, M.S.; BORGES, G.S.C.; SOUSA, K.S.M.; QUIRINO, A.K.R. Componentes principais de parâmetros físico-químicos de mangas cv. Tommy Atkins durante a maturação. Revista Espacios, Caracas, v.38, n. 16, 2017.

EMBRAPA. Médias Anuais da Estação Agrometeorológica de Mandacaru (Juazeiro-BA 09²4'S, 40²6'W). Período 1975-2014. Brasília (DF): Embrapa Semiárido, 2015. Disponível em: http://www. cpatsa.embrapa.br:8080/servicos/dadosmet/cem-anual. html. Acesso em: 08 out. 2020.

FAOSTAT-FAO. Food and agriculture data: mango. 2018. Disponível em: http://www.fao.org/faostat/ en/\#home. Acesso em: 31 jul. 2020.

FILGUEIRAS; H.A.C.; PIMENTEL; C.R.M.; CASTRO; E.B.; MENEZES; J.B.; ALVES; R.E.; AMORIM; T.B.F. Colheita e manuseio pós-colheita. In: FILGUEIRAS, H.A.C. (org.). Frutas do Brasil: manga. Pós-colheita. Fortaleza: Embrapa Agroindústria Tropical, 2001. 25 p.

FLAISHMAN, A.F.; SHARGAL, A., STERN, R.A. The synthetic cytokinin CPPU increases fruit size and yield of 'Spadona' and 'Costia' pear (Pyrus communis L.). The Journal of Horticultural Science and Biotechnology, London, v.76, p.145-149, 2001.

HAJAM, M.A.; HASSAN, G.I.; PARRAY, E.A.; WANI, M.A.; SHABIR, A.; KHAN, I.F.; WANI, A.W.; BHAT, T.A.; MASOODI, L. Transforming fruit production by plant growth regulators. Journal of Pharmacognosy and Phytochemistry, New Delhi, v.7, n.1, p.1613-1617, 2018.

HEDDEN, P. Gibberellins. In: THOMAS, B.; MURRAY, B.G.; MURPHY, D.J. Encyclopedia of applied plant sciences: plant physiology and development. Amsterdam: Elsevier, 2017. v.1, p.411-420.

INSTITUTO ADOLFO LUTZ. Métodos físico-químicos para análise de alimentos. 5.ed. São Paulo: Instituto Adolfo Lutz, 2008. 1020 p.

JAMESON, P.E.; SONG, J. Cytokinin: a key driver of seed yield. Journal of Experimental Botany, Oxford, v.67, n.3 p.593-606, 2016.
KUMAR, R.; KHURANA, A.; SHARMA, A.K. Role of plant hormones and their interplay in development and ripening of fleshy fruits. Journal of Experimental Botany, Oxford, v.65, n.16, p.4561-4575, 2014.

KUMARI, S.; BAKSHI, P.; SHARMA, A.; WALI, V.K.; JASROTIA, A.; KOUR, S. Use of plant growth regulators for improving fruit production in sub tropical crops. International Journal of Current Microbiology and Applied Sciences, Tamilnadu, v.7, n.3, p.659-668, 2018.

LIMA, M.A.C.; SILVA, A.L.; AZEVEDO, S.S.N. Evolução de indicadores do ponto de colheita em manga 'Tommy Atkins' durante o crescimento e a maturação, nas condições do Vale do São Francisco, Brasil. Ciência e Agrotecnologia, Lavras, v.33, n.2, p.432-439, 2009.

LUCENA, E.M.P.; ASSIS, J.S.; ALVES, R.E.; SILVA, V.C.M.; FILHO, J.E. Physical and Chemical changes during the development of 'Tommy Atkins' mangoes in the São Francisco Valley, Petrolina - PE. Revista Brasileira de Fruticultura, Jaboticabal, v.29, n.1, p.96-101, 2007.

MOUCO, M.A.C.; SILVA, D.J.; PRADO, R.M. Mango cultivation in Brazil. In: VALAVI, S.G.; RAJMOHAN, K.; GOLVI, J.N.; PETER, K.V.; THOTTAPPILLY, G. Mango: cultivation in different countries. Houston: Studium Press LLC, 2012. v.2, p.331-345.

OSUNA-ENCISO, T.; CHAVARÍN-NAVARRO, Z.M.; CARRILLO-FASIO, J.A.; VALDEZ-TORRES, J.B.; BASILIO-HEREDIA, J.; BÁEZ-SAÑUDO, M.A.; HERNÁNDEZ-VERDUGO, S.; OSUNA-RODRÍGUEZ, J.M. Efecto de aspersiones de biorreguladores en precosecha sobre el crecimiento y maduración del mango Keitt. Revista Fitotecnia Mexicana, Chapingo, v.42, n.3, p.259-268, 2019.

OZGA, J.; REINECKE, M.D. Hormonal interactions in fruit development. Journal of Plant Growth Regulation, London, v.22, p.73-81, 2003. 
PÉREZ-BARRAZA, M.H.; CANO-MEDRANO, R; AVITIA-GARCÍA, E.; GUTIÉRREZ-ESPINOSA, M.A.; NOLASCO-GONZÁLEZ, Y.; OSUNA-ENCISO, T. Reguladores de crecimiento en mango: su relación con carbohidratos número y tamaño de células. Revista Mexicana de Ciencias Agrícolas, Texcoco, v.19, n.esp., p.3855-3868, 2017.

PÉREZ-BARRAZA, M.H.; OSUNA-ENCISO, T.; GUTIÉRREZ-ESPINOSA, M.A.; SANTIAGO-CRUZ, M.J.; AVITIA-GARCÍA, E.; CANO-MEDRANO, R. Thidiazuron y ácido giberélico en amarre y tamaño de frutos de mango 'ataulfo' polinizados y partenocárpicos. Interciencia, Caracas, v.40, n.10, p.677-683, 2015.

PINTO, A.C.Q. O agronegócio da manga. In: AlBUQUERQUE, A.C.S.; SIlvA, A.G. (ed.). Agricultura tropical: quatro décadas de inovações tecnológicas, institucionais e políticas. Brasília (DF): Embrapa Informação Tecnológica, 2008.

RADEMACHER, W. Chemical regulators of gibberellin status and their application in plant production. Annual Plant Reviews, Hoboken, v.49, p.359-403, 2016.

RAM, S. Naturally occurring hormones of mango and their role in growth and drop of the fruit. Acta Horticulturae, The Hague, v.392, p.43, 1992

SANTOS, C.A.F.; LIMA-NETO, F.P.; COSTA, J.G. Cultivares de manga. In: MOUCO, M.A. O cultivo da mangueira. Petrolina: Embrapa Semiárido, 2015. (sistema de produção)
SAS. SAS ${ }^{\circledR}$ 9.1.3 (TS1M3) for windows Microsoft. Cary: SAS Institute, 2007.

SHAKYA, R.; LAL, M.A. Fruit development and ripening. In: BHATLA, S.C.; LAL, M.A. Plant physiology, development and metabolism. Singapore: Springer, 2018. p.857-883.

SOUZA, M.A.; SIMÕES, W.L.; MESQUISA, A.C.; MOUCO, M.A.C.; CAVALCANTE, B.L.S.; GUIMARÃES, M.J.M. Manejo da quimigação para indução floral da mangueira 'Palmer' no Submédio do Vale do São Francisco. Irriga, Botucatu, v.23, n.3, p.442$453,2018$.

SUMAN, M.; SANGMA, P.D.; MEGHAWAL, D.R.; SAHU, O.P. Effect of plant growth regulators on fruit crops. Journal of Pharmacognosy and Phytochemistry, New Delhi, v.6, p.331-337, 2017.

TAIZ. L; ZEIGER, E. Fisiologia e desenvolvimento vegetal. 6.ed. Porto Alegre: Artmed, 2017. 719 p.

TEIXEIRA, A.H.C. Informações agrometeorológicas do polo Petrolina, PE/Juazeiro, BA - 1963 a 2009. Petrolina: Embrapa Semiárido, 2010. 21p (Documentos, 233). 